\title{
Cdk4 disruption renders primary mouse cells resistant to oncogenic transformation, leading to Arf/p53-independent senescence
}

\author{
Xianghong Zou, ${ }^{1}$ Dipankar Ray, ${ }^{1}$ Aileen Aziyu, ${ }^{1}$ Konstantin Christov, ${ }^{2}$ Alexander D. Boiko,,${ }^{1,3}$ \\ Andrei V. Gudkov, ${ }^{1,3}$ and Hiroaki Kiyokawa ${ }^{1,4}$ \\ Departments of ${ }^{1}$ Molecular Genetics and ${ }^{2}$ Surgical Oncology, University of Illinois College of Medicine, Chicago, Illinois \\ 60607, USA; ${ }^{3}$ Department of Molecular Biology, Lerner Research Institute, the Cleveland Clinic Foundation, \\ Cleveland, Ohio 44195, USA
}

\begin{abstract}
A large number of human cancers display alterations in the Ink4a/cyclin $\mathrm{D} / \mathrm{Cdk} 4$ genetic pathway, suggesting that activation of Cdk4 plays an important role in oncogenesis. Here we report that Cdk4-null mouse embryonic fibroblasts are resistant to transformation in response to Ras activation with dominant-negative (DN) 553 expression or in the Ink4a/Arf-null background, judged by foci formation, anchorage-independent growth, and tumorigenesis in athymic mice. Cdk4-null fibroblasts proliferate at normal rates during early

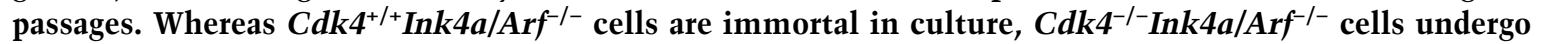
senescence during continuous culture, as do wild-type cells. Activated Ras also induces premature senescence in $\mathrm{Cdk}^{-/-} \mathrm{Ink} 4 \mathrm{a} / \mathrm{Arf} \mathrm{f}^{-/-}$cells and $\mathrm{Cdk}^{-/-}$cells with DNp53 expression. Thus, Cdk4 deficiency causes senescence in a unique Arf/p53-independent manner, which accounts for the loss of transformation potential. Cdk4-null cells express high levels of $\mathrm{p}^{2} 1^{\mathrm{Cip} 1 / \mathrm{Waf} 1}$ with increased protein stability. Suppression of $\mathrm{p}^{\mathrm{Cip} 1 / \mathrm{Waf} 1}$ by small interfering RNA (siRNA), as well as expression of HPV-E7 oncoprotein, restores immortalization and Ras-mediated transformation in $\mathrm{Cdk}^{-/-} \mathrm{Ink} 4 \mathrm{a} / \mathrm{Arf} \mathrm{I}^{-/-}$cells and $\mathrm{Cdk4^{-/- }}$ cells with DNp53 expression. Therefore, Cdk4 is essential for immortalization, and suppression of Cdk4 could be a prospective strategy to recruit cells with inactive Arf/p53 pathway to senescence.
\end{abstract}

[Keywords: Cell cycle; cancer; immortalization; cyclin; Cdk; Ras; Ink4a; p21; stability]

Supplemental material is available at http://www.genesdev.org.

Received August 27, 2002; revised version accepted September 30, 2002.

Perturbed control of the G1 phase of the cell cycle is a critical step for cellular transformation and tumorigenesis (Hartwell and Kastan 1994; Hunter 1997; Hanahan and Weinberg 2000; Sherr 2000). The balance of growthstimulatory and inhibitory signals regulates G1 progression as well as the transition between quiescence (G0) and proliferation (Pardee 1989; Kiyokawa 2002). Cyclin D-dependent kinases play an important role in integrating extracellular signals into the cell-cycle machinery (Sherr 2000). D-type cyclins bind to and activate Cdk4 and Cdk6 during G1 (Matsushime et al. 1992; Meyerson and Harlow 1994). This is followed by activation of Cdk2 in complex with cyclin E in late G1, which is essential for initiation of the S phase. Cdk2 also binds to cyclin A

${ }^{4}$ Corresponding author.

E-MAIL kiyokawa@uic.edu; FAX (312) 413-2028.

Article and publication are at http://www.genesdev.org/cgi/doi/10.1101/ gad.1033002. during $S$ phase, playing a critical role in DNA replication. The activities of Cdk 4 and $\mathrm{Cdk} 6$ are regulated specifically by the Ink4-type inhibitors $\left(\mathrm{p} 16^{\text {Ink4a }}, \mathrm{p} 15^{\text {Ink4b }}\right.$, $\mathrm{p} 18^{\text {Ink4c }}$, and $\left.\mathrm{p} 19^{\text {Ink } 4 \mathrm{~d}}\right)$, whereas Cdk2 is inhibited by the Kip/Cip-type inhibitors (p21 $1^{\text {Cip1/Waf1 }}$, p2 $7^{\text {Kip1 }}$, and p5 $7^{\text {Kip2 }}$; Kiyokawa and Koff 1998; Sherr and Roberts 1999). Cyclin D/Cdk4(Cdk6) phosphorylates retinoblastoma protein $(\mathrm{Rb})$ and the other $\mathrm{Rb}$-related pocket binding proteins p107 and p130 (Ewen et al. 1993; Kato et al. 1993; Leng et al. 2002). Cdk4-dependent phosphorylation of specific sites of $\mathrm{Rb}$ presumably facilitates Cdk2-dependent phosphorylation of other sites (Kitagawa et al. 1996; Connell-Crowley et al. 1997; Zarkowska and Mittnacht 1997; Boylan et al. 1999). The hyperphosphorylation of $\mathrm{Rb}$ promotes conversion of the E2F transcription factors from repressor to transactivator status, which results in expression of various genes essential for the $S$ phase, including cyclins E and A (Nevins 2001). Furthermore, cyclin $\mathrm{D} / \mathrm{Cdk} 4$ in proliferating cells binds to $\mathrm{p} 21^{\text {Cip } 1 / \text { Waf1 }}$ 
and $\mathrm{p} 27^{\mathrm{Kip} 1}$ without being inactivated (Soos et al. 1996; Blain et al. 1997; Sherr and Roberts 1999). These Kip/Cip proteins rather promote assembly of cyclin D/Cdk4 (LaBaer et al. 1997), suggesting that the physical interaction with cyclin D/Cdk4 titrates p21 and p27 populations available for Cdk2 inhibition. Therefore, Cdk4 plays both catalytic and noncatalytic roles in control of G1 progression.

A large number of human cancers show genetic alterations that deregulate cyclin D/Cdk4 (Hirama and Koeffler 1995; Pestell et al. 1999; Sherr 2000). Many glioblastomas, gliomas, and sarcomas display Cdk4 overexpression due to gene amplification (Khatib et al. 1993). Melanoma-prone families have been found to carry germline mutations of $\mathrm{Cdk} 4$ at the $\operatorname{Arg} 24$ residue that render the kinase refractory to Ink4-dependent inhibition (Wolfel et al. 1995; Zuo et al. 1996). Various types of cancer show overexpression of D-type cyclins. More frequent cancer-associated alterations are deletions, mutations, and methylation of the Ink4a/Arf locus (Kamb et al. 1994; Sherr 1998; Sharpless and DePinho 1999). The Ink4a/Arf locus contains two independent genes encoding $\mathrm{p} 16^{\text {Ink4a }}$ and $\mathrm{p} 14^{\text {Arf }}$ (p19 ${ }^{\text {Arf }}$ in mice), which share exons 2 and 3 on alternative reading frames (Quelle et al. 1995). Whereas p16 ${ }^{\text {Ink4a }}$ inhibits Cdk4 and Cdk6, Arf protein interferes with $\mathrm{Mdm} 2$-dependent degradation of the tumor suppressor p53, leading to stabilization of p53 (Pomerantz et al. 1998; Stott et al. 1998; Zhang et al. 1998). Thus, inactivation of the Ink4a/Arf locus results in inappropriate activation of $\mathrm{Cdk} 4$ and rapid degradation of $\mathrm{p} 53$, both of which could contribute to tumorigenesis in distinct but cooperating manners. Consistent with this notion, mice deficient in both $\mathrm{p} 16^{\text {Ink4a }}$ and p19 Arf (Serrano et al. 1996) or mice deficient in p19 Arf with intact p16 $6^{\text {Ink4a }}$ (Kamijo et al. 1997) develop spontaneous tumors. Mice lacking p16 $6^{\text {Ink4a }}$ with intact $\mathrm{p} 19^{\text {Arf }}$ are susceptible to tumorigenesis to a lesser extent (Krimpenfort et al. 2001; Sharpless et al. 2001). These data suggest that activation of Cdk4 plays a critical role in tumorigenesis.

To further clarify the role of Cdk4 in cell-cycle control and tumorigenesis, we recently generated mice with targeted disruption of the Cdk4 gene. Cdk4-null mice are viable, and exhibit diabetes mellitus due to degeneration of pancreatic $\beta$-cells and growth retardation and infertility associated with severe hypoplasia and dysfunction of the pituitary (Tsutsui et al. 1999; Moons et al. 2002a,b). Embryonic fibroblasts (MEFs) from Cdk4null mice proliferate at normal rates, while they display a 4-5-h delay in entry into the cell cycle from quiescence (Tsutsui et al. 1999). Therefore, Cdk4 is ratelimiting for cell-cycle entry but is dispensable for cellcycle progression. However, it was unclear whether Cdk4 plays an essential role in immortalization and transformation. In this study, we demonstrate that Cdk4 is required for Ras-mediated transformation of MEFs, and that $C d k 4$ disruption leads cells to Arf/p53-independent senescence. These findings provide a significant foundation for anticancer therapies that target the cyclin $\mathrm{D} / \mathrm{Cdk} 4$ pathway.

\section{Results \\ Cdk4-null MEFs are resistant to transformation in response to Ras activation and p53 inhibition}

To examine the effect of $C d k 4$ disruption on transformation potential, we prepared $C d k 4^{+/+}$and $C d k 4^{-/-}$MEFs from embryos obtained from intercross breeding of $\mathrm{Cdk}^{+/-}$mice (Tsutsui et al. 1999). Cells at early passages (passage 3-4) were infected with a retrovirus for expression of oncogenic H-Ras ${ }^{\mathrm{Val12}}$ and a dominantnegative p53 mutant (DNp53), previously described as GSE56 (Ossovskaya et al. 1996). DNp53 encodes the amino acids 275-368 of p53, and suppresses p53 activity, presumably by interfering with oligomerization of the protein. Under standard culture conditions with $10 \%$ fetal bovine serum, $\mathrm{Cdk}^{-/-} \mathrm{MEFs}$ proliferated at rates indistinguishable from those of $\mathrm{Cdk}^{+/+} \mathrm{MEFs}$, as demonstrated previously (Tsutsui et al. 1999). Following retroviral transduction of $\mathrm{H}-\mathrm{Ras}^{\mathrm{Val12}}$, with or without DNp53, cells were cultured for $21 \mathrm{~d}$ without splitting and then stained to visualize transformed foci (Fig. 1).
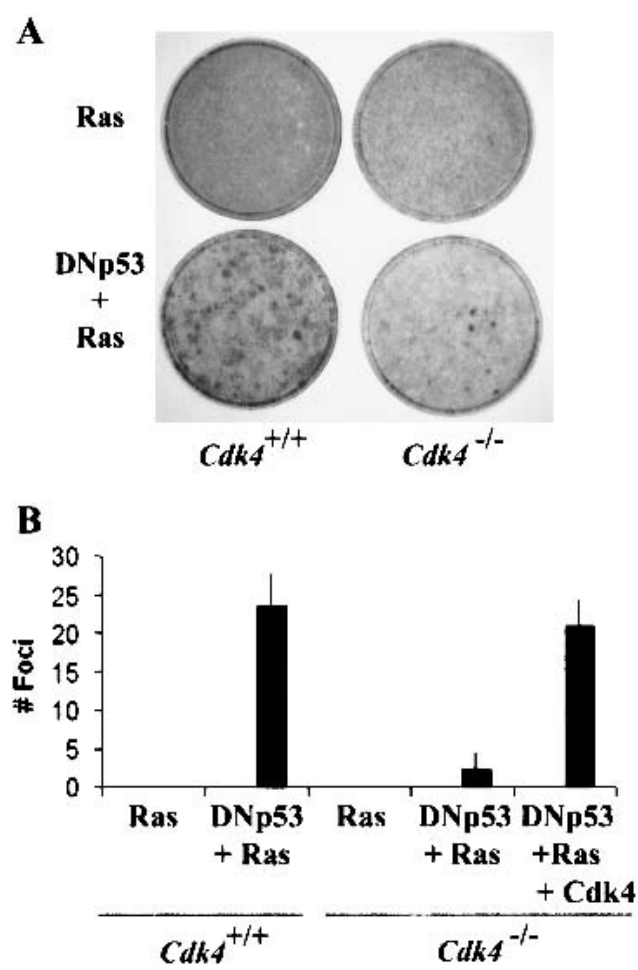

Figure 1. Cdk4-null mouse embryonic fibroblasts are resistant to transformation induced by expression of $\mathrm{H}$-Ras ${ }^{\text {val12 }}$ and dominant-negative p53. (A) Passage 4 mouse embryonic fibroblasts (MEFs) with the indicated genotypes were infected

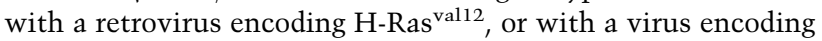
H-Ras ${ }^{\text {val12 }}$ and a dominant-negative p53 (DNp53; amino acids 275-368) with the internal ribosomal entry site. To restore Cdk4 in $\mathrm{Cdk}^{-/-}$MEFs, cells were infected with a Cdk4 retrovirus $48 \mathrm{~h}$ prior to $\mathrm{H}-\mathrm{Ras}^{\text {val12 }}+\mathrm{DNp} 53$. Cells were then cultured in the medium containing $5 \%$ FBS for $21 \mathrm{~d}$. (B) The numbers of foci per $60-\mathrm{mm}$ dish in the assays are expressed as means + S.E.M. from three independent MEF preparations. 
Strikingly, the numbers of foci developed in $\mathrm{Cdk}^{-/-}$ MEF cultures expressing H-Ras ${ }^{\text {Val12 }}$ and DNp53 were $95 \%$ reduced, relative to those in $\mathrm{Cdk}^{+/+}$cultures. Retroviral transduction of $\mathrm{H}-\mathrm{Ras}^{\mathrm{Val12}}$ alone or DNp53 alone did not result in focus formation in either $\mathrm{Cdk}^{+/+}$or $C d k 4^{-/-}$MEFs. Immunoblotting confirmed that the levels of Ras expression were comparable in $\mathrm{Cdk}^{+/+}$and $\mathrm{Cdk}^{-/-}$cells (data not shown). Retroviral transduction of Cdk4 prior to transduction of H-Ras ${ }^{\text {Val12 }}$ and DNp53 restored foci formation (Fig. 1B), confirming that the absence of Cdk4 is responsible for the inhibition of foci formation.

We also examined anchorage-independent growth by plating MEFs in soft agar following retroviral transduction (Supplementary Fig. 1). Whereas $\mathrm{Cdk}^{+/+}$MEFs expressing H-Ras Val12 and DNp53 efficiently developed

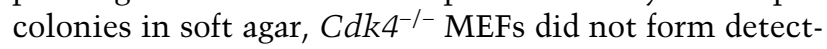
able colonies under the same conditions. MEFs expressing H-Ras ${ }^{\text {Val12 }}$ alone or DNp53 alone formed no colonies regardless of the $C d k 4$ genotype, as expected. These data suggest that Cdk4 disruption inhibits cellular transformation induced by Ras activation and p53 inhibition.

\section{$\mathrm{Cdk}^{-/-}$Ink4a/Arf ${ }^{-/-}$MEFs are resistant to}

Ras-induced transformation

To further examine the effect of Cdk4 deficiency on Rasmediated transformation, we crossed Cdk4-null mice and mice with deletion of the exons 2 and 3 of the Ink $4 a$ / Arf locus (Serrano et al. 1996), and prepared Cdk4 $4^{-1}$ Ink4al $\mathrm{Arf}^{-/-}$and $\mathrm{Cdk}^{+/+} \operatorname{Ink} 4 a / \mathrm{Arf}^{-/-}$MEFs. Cells at early passage were infected with retrovirus for $\mathrm{H}$-Ras ${ }^{\mathrm{Val12}}$ or control virus, and then cultured for $17 \mathrm{~d}$ without splitting. $\mathrm{Cdk}^{+/+}$Ink4a/Arf ${ }^{-/-}$MEFs efficiently developed transformed foci upon retroviral transduction of $\mathrm{H}$ Ras (Fig. 2), as previously demonstrated (Serrano et al. 1996). In contrast, Cdk $4^{-l-}$ Ink4a/Arf ${ }^{-/}$MEFs expressing H-Ras ${ }^{\text {Val12 }}$ poorly formed foci, showing $93 \%$ reduction in number. No colonies grew when $\mathrm{Cdk}^{-/-} \mathrm{Ink} 4 \mathrm{a} / \mathrm{Arf}^{-/-}$ MEFs were inoculated in soft agar following H-Ras ${ }^{\text {Val12 }}$ transduction, whereas $\mathrm{Cdk}^{+/+} \operatorname{Ink} 4 a / \mathrm{Arf}^{-/-}$MEFs readily developed colonies (data not shown). These observations suggest that Cdk4 plays a major role in transformation of MEFs induced by Ras activation in the Ink4a/Arf-null background.

Cdk4-null cells isolated from foci are not tumorigenic in vivo

To determine whether Cdk4-null cells that formed foci were tumorigenic in vivo, we injected athymic mice with $\mathrm{Cdk}^{+/+}$and $\mathrm{Cdk} 4^{-/-}$MEF clones isolated from foci induced by H-Ras ${ }^{\text {Val12 }}$ and DNp53, as shown in Figure 1. $C d k 4^{-/-}$clones exhibited slower proliferation in culture, compared with $\mathrm{Cdk}^{+/+}$clones (data not shown). Five independent clones with each genotype were tested (Fig. 3). At $21 \mathrm{~d}$ postinjection, all five $C d k 4^{+/+}$clones displayed tumor growth, with diameters of $1.7 \pm 0.5 \mathrm{~cm}$ (mean \pm S.E.M.). In contrast, none of five $C d k 4^{-/-}$clones
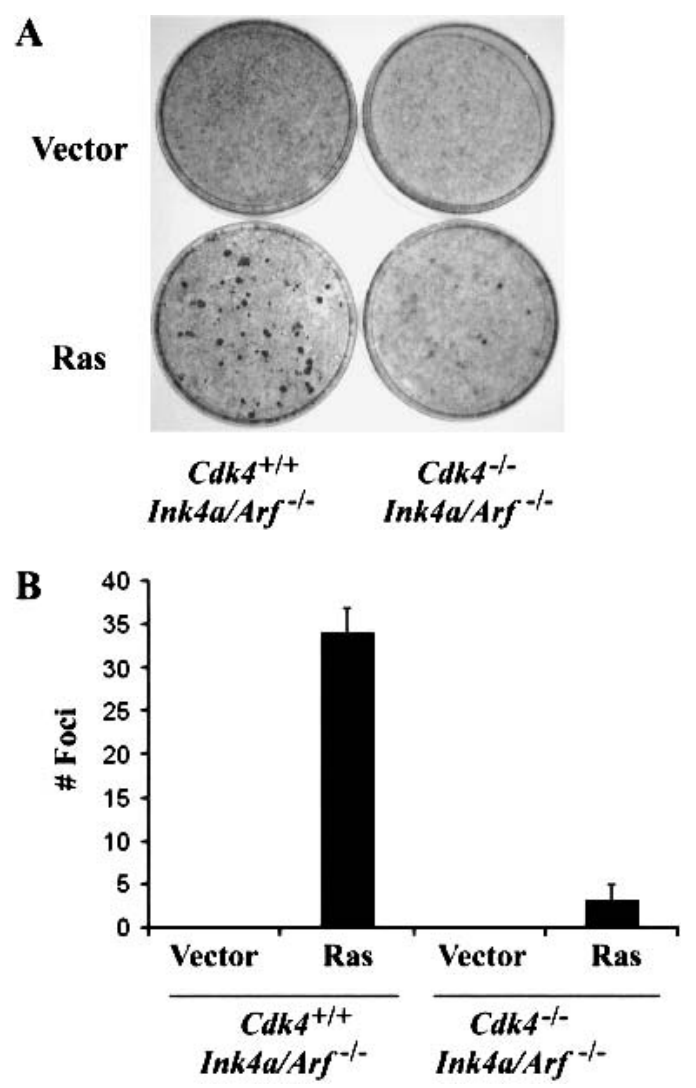

Figure 2. $\mathrm{Cdk}^{-/-} I n k 4 a / A r f^{-/-}$MEFs are resistant to $\mathrm{H}-$ Ras $^{\text {val12 }}$-induced transformation. (A) Passage 4 MEFs were infected with a retrovirus encoding H-Ras ${ }^{\text {val12 }}$, or with a control virus with the pBabe-hygro vector. Cells were then cultured in the medium containing $5 \%$ FBS for $17 \mathrm{~d}$. (B) The numbers of foci per $60-\mathrm{mm}$ dish in the assays are expressed as means + S.E.M. from three independent MEF preparations.

developed detectable tumors in athymic mice during the 6-wk monitoring period. We also examined the in vivo tumorigenicity of $\mathrm{Cdk}^{+/+} \operatorname{Ink} 4 \mathrm{a} / \mathrm{Arf}^{-/}$and $\mathrm{Cdk}^{4^{-1}}$ Ink4a/Arf ${ }^{-1-}$ MEF clones isolated and expanded from foci induced by H-Ras ${ }^{\mathrm{Val12}}$, as shown in Figure 2. $\mathrm{Cdk}^{\mathrm{C}^{-1}}$ Ink $4 \mathrm{a} / \mathrm{Arf}^{-{ }^{-}}$clones did not develop detectable tumors in athymic mice, whereas mice injected with $\mathrm{Cdk} 4^{+/+}$Ink $4 a / \mathrm{Arf}^{-/-}$clones readily displayed large tumors (Fig. 3). These data suggest that Cdk4 disruption abrogates tumorigenicity of MEFs induced by Ras activation with p53 inhibition or Ink4a/Arf disruption.

\section{Cdk4 deficiency leads Ink4a/Arf-null MEF to senescence}

It is well established that MEFs lacking p53 or Arf are immortal in culture, devoid of "culture shock"-induced senescence, and are readily transformed by activated Ras (Kamijo et al. 1997; Serrano et al. 1997). Immortalization is a process required for the multistep oncogenic transformation. To further investigate the mechanism of the transformation-inhibitory action of $\mathrm{Cdk} 4$ disruption, we 
A

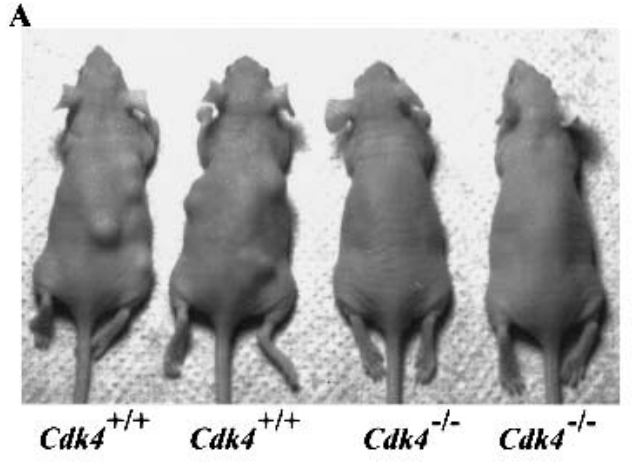

Cells from foci in Ras + DNp53 transduced cultures

B

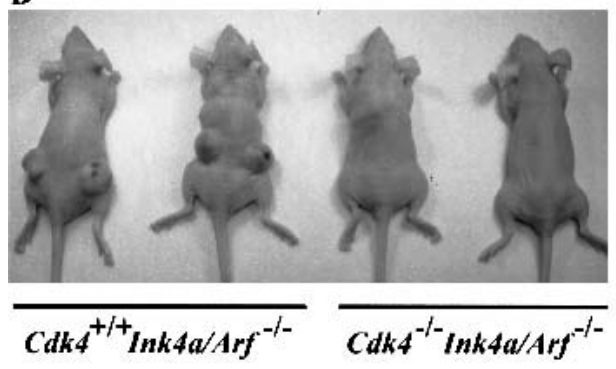

Cells from foci in Ras transduced cultures

Figure 3. Cdk4-null embryonic fibroblasts isolated from foci are not tumorigenic in athymic mice. $(A)$ Foci were isolated from the confluent cultures at $21 \mathrm{~d}$ following retrovirus transduction of H-Ras ${ }^{\text {val12 }}$ and DNp53 (see Fig. 1). (B) Foci were isolated from the confluent cultures at $17 \mathrm{~d}$ following H-Ras ${ }^{\text {val-12 }}$ expression (see Fig. 2). Cells were then expanded, and injected into athymic mice $\left(10^{6}\right.$ cells per site). Mice were examined $21 \mathrm{~d}$ after injection.

examined whether $\mathrm{Cdk}^{-/-}$Ink4a/Arf-/- MEFs showed an immortal phenotype similar to $\mathrm{Cdk}^{+/+}$Ink $4 a / \mathrm{Arf}^{-/-}$ MEFs. Cells at a late passage (passage 11) were inoculated at a low density (1000 cells per dish) and cultured for $10 \mathrm{~d}$ to score colonies derived from isolated cells (Fig. 4A). $\mathrm{Cdk}^{+/+}$Ink $4 a /$ Arf $^{-/-}$MEFs formed $>200$ large colonies, indicating clonogenic proliferation with high plat-

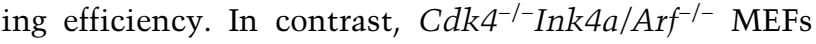
exhibited very few colonies. These observations suggest that Cdk4 disruption impairs clonogenic proliferation of Ink4a/Arf-null cells. We further assessed the proliferative lifespan of $\mathrm{Cdk}^{+/+} \operatorname{Ink} 4 \mathrm{a} / \mathrm{Arf}^{-{ }^{--}}$and $\mathrm{Cdk}^{-/-} \operatorname{Ink} 4 \mathrm{al}$ $\mathrm{Arf}^{-1-}$ MEFs, monitoring population doublings during continuous culture according to the 3T3 protocol (Fig. 4B). $\mathrm{Cdk}^{4^{+/+}}$Ink $4 \mathrm{a} / \mathrm{Arf}^{-/-}$MEFs displayed escape from senescence, as expected. In contrast, $\mathrm{Cdk} 4^{-/-}$Ink $4 a / \mathrm{Arf}^{-/-}$ MEFs underwent growth arrest after 22-24 population doublings, similarly to wild-type MEFs. Cdk4 ${ }^{-/}$Ink4a/ $\mathrm{Arf}^{-/-}$cells at late passages displayed a flat enlarged morphology and senescence-associated $\beta$-galactosidase $(\mathrm{SA} \beta$ gal) activity (Fig. 4C), which are characteristic of cellular senescence (Dimri et al. 1995). The senescence phenotype was also observed in cells isolated from foci of $\mathrm{Cdk}^{-/-}$MEFs expressing H-Ras ${ }^{\mathrm{Val12}}$ and DNp53, and in cells isolated from foci of $C d \mathrm{k}^{4^{-/-}}$Ink $4 a / \mathrm{Arf}^{-/-}$MEFs expressing H-Ras ${ }^{\text {Val12 }}$ (data not shown). These data suggest that the absence of Cdk4 induces senescence even with Ink4a/Arf disruption or p53 inhibition, which could account for the inhibition of oncogenic transformation.

\section{Cdk4-null MEFs express high levels of p21 ${ }^{\text {Cip1/Waf1 }}$} with increased stability

To further investigate the mechanism of the resistance to Ras-mediated transformation in Cdk4-null cells, we examined the expression of proteins that regulate senescence. In primary mouse and human cells, Ras activation

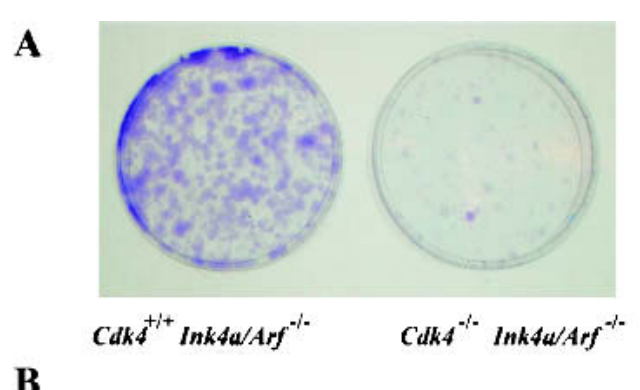

B
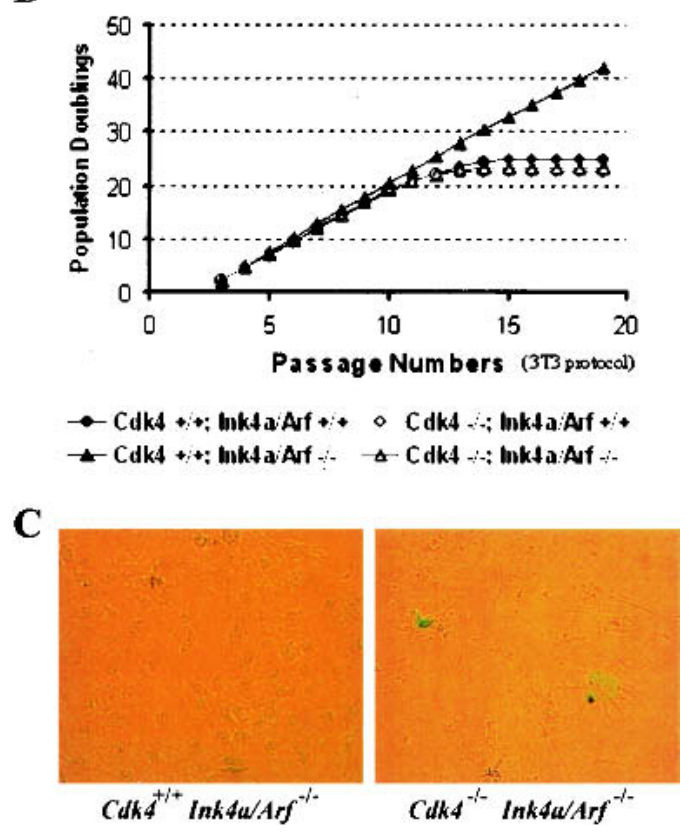

Figure 4. Cdk4 disruption renders cells insensitive to immortalization associated with Ink4a/Arf deficiency. $(A)$ MEFs at passage 11 were plated at a low density $\left(1 \times 10^{3}\right.$ cells per $60-\mathrm{mm}$ dish), and cultured for $10 \mathrm{~d}$. Colonies grown from isolated cells were stained with crystal violet. $(B)$ Primary MEFs with indicated genotypes were propagated in culture according to the 3T3 protocol. Accumulated numbers of population doublings are shown. The data represent experiments using three independent MEF preparations for each genotype. $(C)$ Senescence-associated $\beta$-galactosidase (SA $\beta$-gal) staining. MEFs at passage 12 were inoculated at $3 \times 10^{3}$ cells per $60-\mathrm{mm}$ dish, and $10 \mathrm{~d}$ later, the cells were stained for SA $\beta$-gal, as described in Materials and Methods. 
or continuous passage in culture induces the expression of $\mathrm{p} 15^{\text {Ink4b }}, \mathrm{p} 16^{\text {Ink4a }}$, and $\mathrm{p} 21^{\text {Cip1/Waf1 }}$, as well as p19 Arf (or p14 Arf in human cells; Sherr and DePinho 2000). $\mathrm{Cdk}^{+/+}$and $\mathrm{Cdk}^{-/-} \mathrm{MEF}$ displayed similar induction of the expression of $\mathrm{p} 15^{\text {Ink } 4 \mathrm{~b}}, \mathrm{p} 16^{\text {Ink } 4 \mathrm{a}}$, and $\mathrm{p} 19^{\text {Arf }}$ following H-Ras Val12 transduction (Fig. 5A). In contrast, the basal level of p21 Cip1/Waf1 expression was significantly higher in $C d k 4^{-/-}$cells, relative to $C d k 4^{+/+}$cells, and H-Ras Val12 transduction increased $\mathrm{p} 21^{\text {Waf1/Cip } 1}$ expression even

$\mathbf{A}$

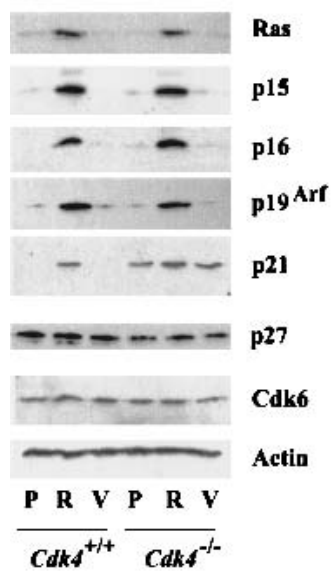

B
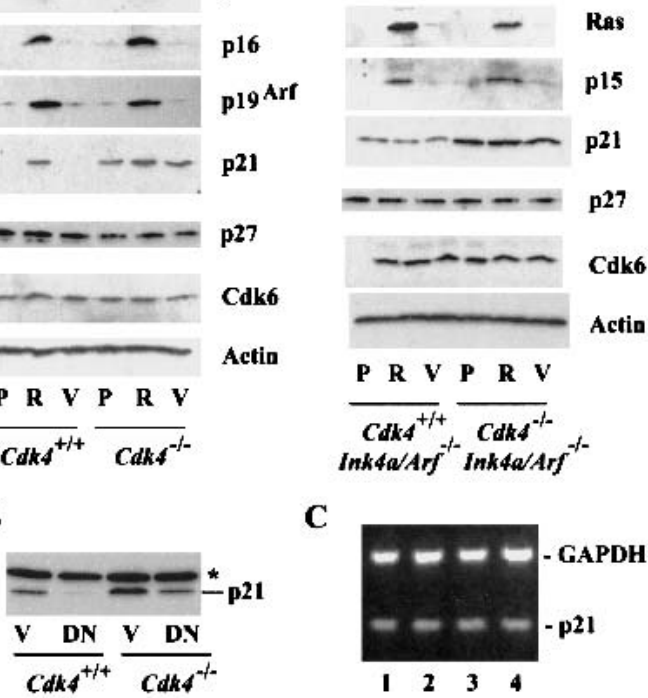

C

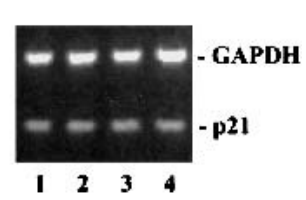

D

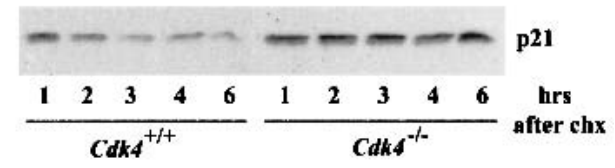

Figure 5. Cdk4-null MEFs express high levels of $\mathrm{p} 21^{\text {Cip1/Waf1 }}$ with increased stability regardless of the Arf/p53 status. (A) Cells with indicated genotypes were infected with retrovirus constructed from pBabe-H-Ras ${ }^{\text {val12 }}$ or pBabe-hygro control vector. Infected cells were selected for $72 \mathrm{~h}$ in the presence of 50 $\mathrm{\mu g} / \mathrm{mL}$ hygromycin, and were then analyzed by immunoblotting for the proteins indicated. $\mathrm{P}$, uninfected proliferating cells (no selection); $\mathrm{R}$, cells infected with $\mathrm{H}$-Ras ${ }^{\text {val12 }}$ retrovirus; $\mathrm{V}$, cells infected with vector control virus. $(B)$ Cells were infected with retrovirus constructed from LXSN-dominant-negative (DN) p53 or LXSN control vector (V). Infected cells were selected for $72 \mathrm{~h}$ in the presence of $2 \mu \mathrm{g} / \mathrm{mL}$ puromycin, and then analyzed by immunoblotting for the expression of $\mathrm{p} 21^{\text {Cip } 1 / \text { Waf } 1}$. *, a band with nonspecific immunoreactivity. $(C)$ Expression of p $21^{\text {Cip1/Waf1 }}$ mRNA is unaltered. Exponentially proliferating cells at passage 4 were analyzed by RT-PCR for the expression of $221^{\text {Cip1/Waf1 }}$ mRNA and GAPDH mRNA. The genotypes of

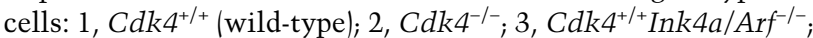

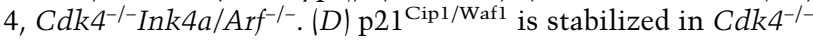
cells. Exponentially proliferating cells were treated with $40 \mu \mathrm{g} /$ $\mathrm{mL}$ cycloheximide $(\mathrm{chx})$ for the times indicated, and cellular levels of $\mathrm{p} 21^{\mathrm{Cip} 1 / \text { Waf1 }}$ were determined by immunoblotting. These data represent experiments using three independent cell preparations at passage 3 or 4 for each genotype.

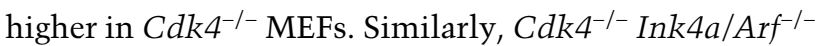
MEFs showed higher levels of $\mathrm{p} 21^{\mathrm{Cip} 1 / \text { Waf1 }}$ than $\mathrm{Cdk} 4^{+/+}$ Ink $4 a / \mathrm{Arf}^{-/-}$MEFs. H-Ras ${ }^{\text {Val12 }}$ did not significantly increase $\mathrm{p} 21^{\text {Waf1/Cip } 1}$ expression in cells with Ink4a/Arf disruption, consistent with the notion that $\mathrm{p} 19^{\text {Arf }}$ plays an essential role in stabilizing p53 and inducing p21 Cip1/Waf1 upon Ras activation. H-Ras ${ }^{\text {Val12 }}$ did not alter the expression of $\mathrm{Cdk} 6$ or $\mathrm{p} 27^{\mathrm{Kip} 1}$, regardless of the Cdk4 status. To determine whether the increased basal levels of $\mathrm{p} 21^{\text {Waf1/Cip } 1}$ in Cdk4-null cells are associated with p53 activity, we further examined the effect of DNp53 transduction on cellular expression of p21 Cip1/Waf1 (Fig. 5B). DNp53 significantly down-regulated $\mathrm{p} 21^{\mathrm{Cip} 1 / \text { Waf } 1}$ expression in both $\mathrm{Cdk} 4^{+/+}$and $\mathrm{Cdk} 4^{-/-}$MEFs, confirming the role of $\mathrm{p} 53$ in $\mathrm{p} 21^{\mathrm{Cip} 1 / \mathrm{Waf} 1}$ transcription. In $\mathrm{Cdk}^{-/-} \mathrm{MEFs}$, which showed higher basal levels of $\mathrm{p} 21^{\mathrm{Cip} 1 / \text { Waf1 }}$ expression, DNp53 transduction decreased $\mathrm{p} 21^{\mathrm{Cip} 1 / \mathrm{Waf} 1}$ only to a level comparable to the basal levels in $\mathrm{Cdk}^{+/+}$cells, suggesting that Cdk4 deficiency increases $\mathrm{p} 21^{\mathrm{Cip} 1 / \mathrm{Waf} 1}$ in a p53-independent manner. In contrast to the increased protein levels, the cellular amounts of $\mathrm{p} 21^{\mathrm{Cip} 1 / \mathrm{Waf} 1}$ mRNA were unchanged

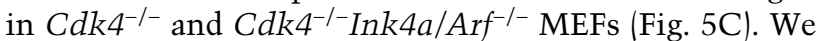
further determined that $\mathrm{p} 21^{\mathrm{Cip} 1 / \mathrm{Waf} 1}$ in $C d \mathrm{k} 4^{-/-}$MEFs is significantly more stable than that in $\mathrm{Cdk}^{+/+} \mathrm{MEFs}$, examining the degradation of $\mathrm{p} 21^{\mathrm{Cip} 1 / \mathrm{Waf} 1}$ in cells treated with a protein synthesis inhibitor, cycloheximide (Fig. $5 \mathrm{D})$. Under these conditions, the degradation of $\mathrm{p} 27^{\mathrm{Kip} 1}$ was similar in $\mathrm{Cdk}^{-/-}$and $\mathrm{Cdk}^{+/+} \mathrm{MEFs}$ (data not shown). These data suggest that Cdk4 deficiency results in a specific increase in $\mathrm{p} 21^{\mathrm{Cip} 1 / \mathrm{Waf} 1}$, which could play a role in the senescence response.

Suppression of $p 21^{\text {Cip1/Waf1 }}$ by siRNA restores immortalization and Ras-mediated transformation in Cdk4-null MEFs

To determine whether elevated $\mathrm{p} 21^{\mathrm{Cip} 1 / \mathrm{Waf} 1}$ expression in Cdk4-null MEFs is required for the inhibition of immortalization and transformation, we used small interfering RNA (siRNA) to suppress cellular expression of p21 Cip1/Waf1. A 21-mer double-stranded RNA designed specifically from residues 136-156 of the coding region of mouse $\mathrm{p} 21^{\text {Cip1/Waf1 }}$ mRNA was able to suppress cellular $21^{\text {Cip1/Waf } 1}$ expression by more than $90 \%$, suggesting that a majority of cells were successfully transfected (Fig. 6A). The siRNA-based suppression of $\mathrm{p} 21^{\text {Cip1/Waf1 }}$ significantly restored clonogenic proliferation in lowdensity cultures of $\mathrm{Cdk}^{-1-} \mathrm{Ink} 4 \mathrm{a} / \mathrm{Arf}^{-1-}$ MEFs (Fig. $6 \mathrm{~B}, \mathrm{C})$, suggesting that the elevated $\mathrm{p} 21^{\mathrm{Cip} 1 / \text { Waf } 1}$ expression plays a critical role in the limited proliferative lifespan. Moreover, siRNA-mediated suppression of p $21^{\text {Cip1/Waf } 1}$ was able to restore foci formation significantly in $\mathrm{Cdk}^{-/-}$Ink $4 a / \mathrm{Arf}^{-/-}$cultures in response to $\mathrm{H}$ Ras $^{\text {Val12 }}$ transduction (Fig. 6D). The numbers of Ras-induced foci in siRNA-treated $\mathrm{Cdk}^{-/-}$Ink $4 a / \mathrm{Arf}^{-/-}$cultures were about $75 \%$ of those in control $C d k 4^{+/+} \operatorname{Ink} 4 a /$ Arf ${ }^{-1-}$ cultures $(24 \pm 3$ vs. $32 \pm 4$, mean \pm S.E.M., $\mathrm{n}=3$ ). The anti-p21 Cip1/Waf1 siRNA treatment increased foci formation modestly $(\sim 25 \%)$ in $\mathrm{Cdk}^{4^{+/}} \operatorname{Ink}_{4} \mathrm{a} / \mathrm{Arf}^{-{ }^{-}}$cul- 
Zou et al.

A

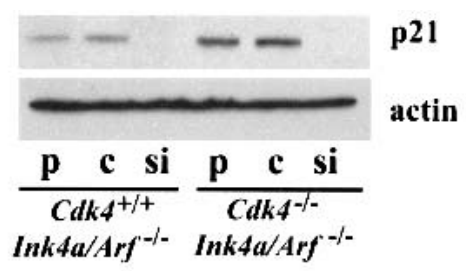

C

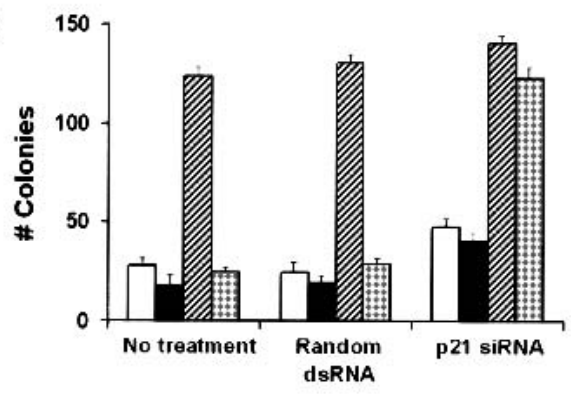

B

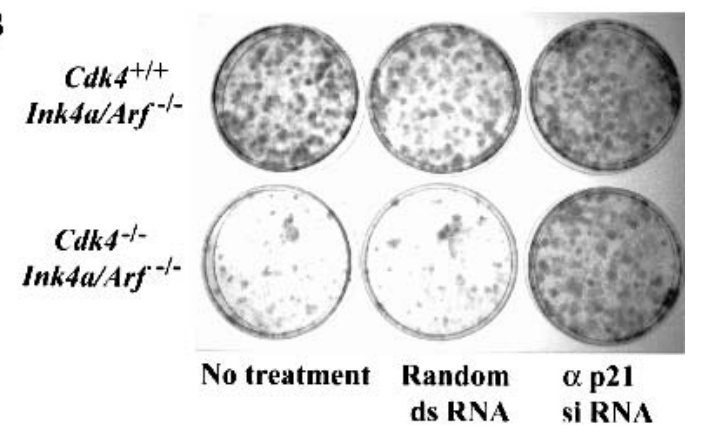

D

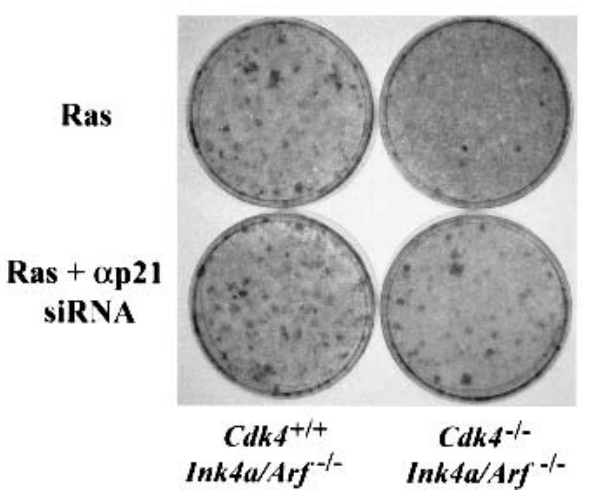

Figure 6. Suppression of $\mathrm{p} 21^{\text {Cip } 1 / \text { Waf } 1}$ expression by siRNA restores immortalization and transformation in Cdk4 $4^{-/-}$Ink $4 a / A r f^{-/-}$ MEFs. (A) Cells at passage 10 were transfected with siRNA that specifically targets $\mathrm{p} 21^{\text {Cip } 1 / \text { Waf } 1} \mathrm{mRNA}$ or with random doublestranded (ds) RNA. Cellular expression of $\mathrm{p} 21^{\text {Cip } 1 / \text { Waf } 1}$ was analyzed by immunoblotting at $72 \mathrm{~h}$ after transfection. $\mathrm{p}$, nontransfected proliferating cells; c, cells transfected with control random dsRNA; si, anti-p21 Cip1/Wafl siRNA. (B) Cells at passage 10 were transfected with the anti-p21 siRNA or control dsRNA, and $24 \mathrm{~h}$ later plated at a density of $1 \times 10^{3}$ cells/plate. $(C)$ Colonies $(>2 \mathrm{~mm})$ were counted at $10 \mathrm{~d}$ postplating, and the numbers are expressed as means + S.E.M. from three independent cell preparations. Open columns,

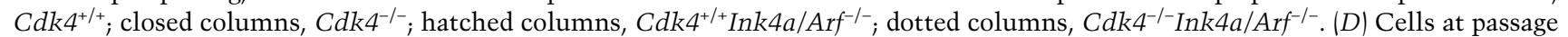
4 were transfected with the anti-p2 $1^{\text {Cip1/Waf1 }}$ siRNA or control dsRNA, and $24 \mathrm{~h}$ later infected with H-Ras ${ }^{\text {val-12 }}$ retrovirus. Foci formation was scored at $15 \mathrm{~d}$ posttransfection.

tures. Transfection of the anti-p21 $1^{\text {Cip1/Waf1 }}$ siRNA also restored foci formation significantly in $\mathrm{Cdk}^{-1-} \mathrm{MEFs}$ with transduction of H-Ras ${ }^{\text {Val12 }}$ and DNp53 (data not shown). These data suggest that increased expression of p21 $1^{\text {Cip } 1 / \text { Waf1 }}$ by protein stabilization, which is independent of the Arf/p53 function, plays an essential role in the resistance of $C d k 4$-null cells to immortalization and Ras-mediated transformation.

\section{The HPV E7 protein fully restores transformation in Cdk4-null MEF}

The E7 oncoprotein of the human papillomavirus-16 (HPV) inactivates $\mathrm{Rb}$ by sequestration and destabilization (Dyson et al. 1989; Boyer et al. 1996). E7 has also been shown to bind to the $\mathrm{C}$ terminus of $\mathrm{p} 21^{\mathrm{Cip} 1 / \text { Wafl }}$ and inactivate its Cdk-inhibitory and replication-inhibitory actions (Funk et al. 1997). Thus, we attempted to determine whether the expression of E7 could restore the transformation potential in Cdk4-null cells (Fig. 7). E7 was expressed in $\mathrm{Cdk}^{+/+} \operatorname{Ink} 4 a / \mathrm{Arf}^{-1-}$ and $\mathrm{Cdk}^{-I^{-I}}$ Ink4al Arf $^{-1}$ MEFs by retroviral transduction, followed by transduction of $\mathrm{H}-\mathrm{Ras}^{\mathrm{Val12}}$ or control vector. $\mathrm{Cdk}^{-/}{ }^{-I} \mathrm{Ink} 4 \mathrm{al}$ $\mathrm{Arf}^{-/-}$MEFs expressing H-Ras ${ }^{\text {Val12 }}$ and E7 developed a number of transformed foci comparable to $\mathrm{Cdk}^{+/+} \operatorname{Ink} 4 \mathrm{al}$ Arf $^{-/-}$MEFs expressing H-Ras val12 with or without E7. Expression of E7 alone did not result in foci formation. The E7 retrovirus also restored foci formation in $\mathrm{Cdk}^{-/-}$ MEFs upon expression of H-Ras ${ }^{\text {Val12 }}$ and DNp53 almost completely (data not shown). These data indicate that the HPV E7 oncoprotein fully restores the transformation potential of Cdk4-disrupted cells.

\section{Discussion}

In this study we have demonstrated that Cdk4-null MEFs are resistant to Ras-mediated oncogenic transformation. Cdk4-null MEFs proliferate normally under optimal growth-promoting conditions, whereas cell-cycle entry from serum deprivation-induced quiescence is modestly delayed (Tsutsui et al. 1999). Ras activation with p53 inhibition or Ink4a/Arf disruption in Cdk4null cells results in dramatically reduced foci formation and no detectable proliferation in soft agar. These data suggest that $C d k 4$ disruption suppresses the two hallmarks of transformed phenotype, lack of contact inhibition and anchorage-independent proliferation (Hartwell and Kastan 1994; Hanahan and Weinberg 2000). More- 
$\mathbf{A}$

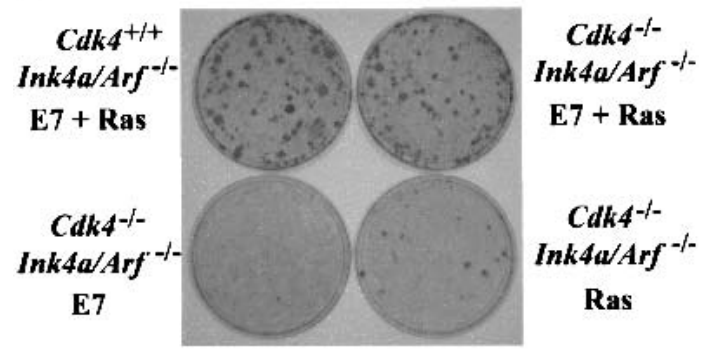

B

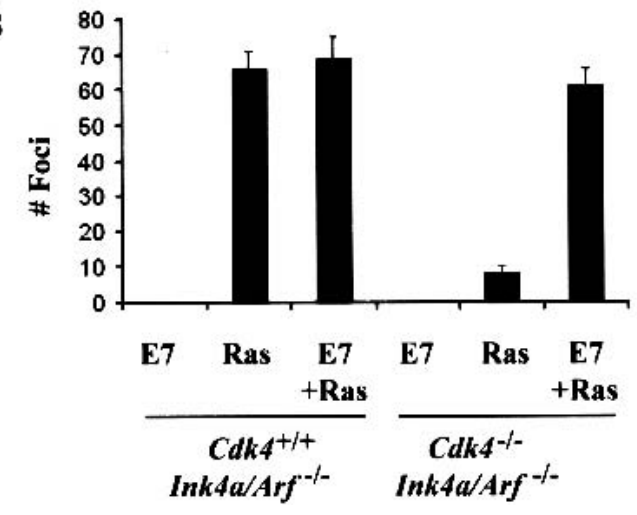

Figure 7. Human papillomavirus E7 oncoprotein restores Rasmediated transformation of $\mathrm{Cdk}^{-/-}$Ink $4 a / \mathrm{Arf}^{-/-}$MEFs. (A) Passage 4 MEFs with indicated genotypes were infected with E7 retrovirus or control virus, followed by infection with $\mathrm{H}-\mathrm{Ras}^{\mathrm{val}-12}$ retrovirus or control virus at a $24-\mathrm{h}$ interval. Cells were then cultured in the medium containing $5 \%$ FBS for $17 \mathrm{~d}$. $(B)$ The numbers of foci per $60-\mathrm{mm}$ dish in the assays are expressed as means + S.E.M. from three independent MEF preparations.

over, rare $C d k 4$-null cells that have apparently lost contact inhibition are not tumorigenic in athymic mice. These observations provide potentially significant insight into prospective therapeutic strategies, implying that genetic or pharmacological suppression of Cdk4 could be an effective approach to render cells insensitive to oncogenic stimuli, without detrimental effects on normal cell-cycle progression. Indeed, we recently demonstrated that Cdk4-null mice display 97\% reduction in susceptibility to carcinogen (DMBA and TPA)-induced skin tumorigenesis (Rodriguez-Puebla et al. 2002). Keratinocytes of $C d k 4$-null mice exhibit normal proliferation and differentiation, indicating that $C d k 4$ disruption abrogates transformation potential in vivo without affecting tissue development. Other recent studies demonstrated that cyclin D1-null mice are resistant to skin tumorigenesis induced by the same carcinogens (Robles et al. 1998) and also insensitive to mammary tumorigenesis mediated by MMTV-Ras or Neu (Yu et al. 2001). However, it has been shown that 3T3-immortalized cyclin D1-null MEF clones are sensitive to Ras-induced transformation (Yu et al. 2001). This is in contrast to the transformation resistance of Cdk4-null primary MEFs demonstrated in the present study. It is unknown whether cyclin D1 deficiency leads cells to premature senescence. It remains to be determined whether Ras- induced transformation of cyclin D1-null MEFs is related to uncharacterized genetic alterations during 3T3 immortalization, for example, $\mathrm{Rb}$ mutations, or activation of Cdk4 by other cyclins, such as cyclins D2 and D3.

The present study provides evidence that $C d k 4$ disruption inhibits transformation by recruiting cells to senescence under conditions of p53 inhibition or Ink4a/Arf disruption, which normally immortalize cells (Serrano et al. 1996; Kamijo et al. 1997). This finding is important in the light of an emerging concept that cellular senescence or organismal aging is a major tumor suppressive mechanism in mammals (Sharpless and DePinho 2002). Expression of activated Ras in primary fibroblasts induces premature senescence phenotypes, such as G1 arrest, the large flat morphology, and SA $\beta$-gal activity, indistinguishable from replicative or "culture shock"-induced senescence (Serrano et al. 1997; Sherr and DePinho 2000). To induce senescence, $\mathrm{p} 16^{\text {Ink4a }}$ and $\mathrm{p} 19^{\text {Arf }}$ function in parallel yet interacting pathways (Fig. 8; Carnero et al. 2000; Sherr and DePinho 2000). Whereas p16 ${ }^{\text {Ink4a }}$ inhibits Cdk4 and Cdk6, p19 Arf increases p21 Cip1/Waf1 transcription by p53 stabilization, consequently inhibiting cyclin $\mathrm{E}(\mathrm{A}) / \mathrm{Cdk} 2$. The inhibition of these G1-Cdks results in G1 arrest with decreased phosphorylation of $\mathrm{Rb}$ and other G1/S-specific substrates. Thus, the senescence response upon oncogene activation forms a safeguard mechanism against transformation. MEFs lacking p19 Arf or p53 show the alternative response to Ras activation, undergoing transformation instead of senescence (Kamijo et al. 1997). These observations indicate essential roles for the Arf/p53 pathway in senescence-dependent tumor suppression. Coexpression of an "immortalizing oncogene," such as adenovirus E1A or c-myc, with activated Ras can also transform MEFs (de Stanchina et al. 1998; Zindy et al. 1998). It is speculated that these immortalizing oncogenes trigger apoptotic response via the Arf/p53 checkpoint pathway, and select for emergence of cell variants that have lost Arf or $p 53$ function (Sherr and DePinho 2000). Consistently, Cdk4-null

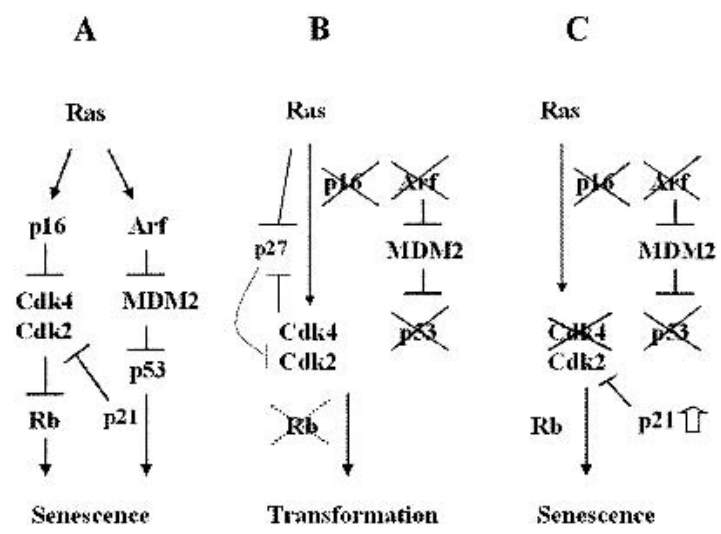

Figure 8. Effects of Cdk4 disruption on the pathways controlling senescence and transformation. (A) Senescence response of wild-type cells to Ras activation. (B) Ras-induced transformation with inactivated Ink4a/Arf/p53 pathway. (C) Senescence rendered by Cdk4 disruption. 
MEFs are resistant to transformation in response to retroviral transduction of c-Myc and $\mathrm{H}-\mathrm{Ras}^{\mathrm{Val12}}$ (X. Zou and H. Kiyokawa, unpubl.). Whereas Ras triggers cell cycleinhibitory changes in the expression of $\mathrm{p} 16^{\text {Ink4a }}, \mathrm{p} 19^{\text {Arf }}$, $\mathrm{p} 53$, and $\mathrm{p} 21^{\mathrm{Cip} 1 / \mathrm{Waf} 1}$, Ras also increases transcription of cyclin D1, which results in activation of Cdk4 (Pestell et al. 1999). Furthermore, Ras up-regulates Cdk2 activity by destabilizing p $27^{\text {Kip } 1}$ (Pruitt and Der 2001). These cell cycle-promoting actions are important for Ras-mediated oncogenic transformation. Therefore, the Arf/p53 pathway normally determines whether Ras activation results in premature senescence or transformation. Senescence of Cdk4-null MEFs without Ink4a/Arf or p53 function suggests that Cdk4 plays a key role in the oncogenic mechanism that converts the cell fate from senescence to transformation, in response to genetic or epigenetic alterations in the Arf/p53 checkpoint pathway. Cdk4 disruption is a unique approach to activate the senescence-dependent tumor suppressive mechanism in cells even with Ink4a/Arf or p53 inactivated.

Immortalization of Cdk4-null cells restored by antip $21^{\text {Cip } 1 / \text { Waf } 1}$ siRNA indicates that $\mathrm{p} 21^{\text {Cip } 1 / \text { Waf } 1}$ plays a critical role in the Arf/p53-independent senescence facilitated by Cdk4 deficiency. However, p21 ${ }^{\text {Cip } 1 / \text { Waf1 }}$-null MEFs with intact Cdk4 senesce normally (Pantoja and Serrano 1999), and MEFs from p21 Cip1/Waf1 , Cdk4-double null mice poorly undergo transformation upon expression of H-Ras ${ }^{\text {Val12 }}$ and DNp53 (X. Zou and H. Kiyokawa, unpubl.). These apparently differential effects of p21 Cip1/Waf1 inactivation may result from the difference between germline disruption and acute somatic loss of p21 Cip1/Waf1.$p 21^{\text {Cip1/Waf1 }}$-null mice may undergo developmental adaptation to the absence of $\mathrm{p} 21^{\mathrm{Cip} 1 / \mathrm{Waf} 1}$, for which other Kip/Cip inhibitors and possibly p130 /Coats et al. 1999), could account. In contrast, the siRNA-based p $21^{\text {Cip1/Waf1 }}$ suppression in MEFs could have more dramatic effects, whereas with intact Arf, the immortalizing effect of anti- p21 $1^{\text {Cip1/Waf1 }}$ siRNA was minimum (Fig. 6C). It is also possible that a cell cycle-inhibitory action of $\mathrm{p} 19^{\text {Arf }}$ independent of $\mathrm{p} 53$ or $\mathrm{p} 21^{\mathrm{Cip} 1 / \text { Waf } 1}$ (Ferbeyre et al. 2002) may play a role in inducing senescence in p21 Cip1/Waf1-null MEFs. Cdk4-null MEFs display increased expression of $\mathrm{p} 21^{\mathrm{Cip} 1 / \text { Waf } 1}$ with enhanced protein stability. Cdk4-null MEFs expressing H-Ras ${ }^{\text {Val12 }}$ display increased amounts of $\mathrm{p} 21^{\mathrm{Cip} 1 / \mathrm{Waf} 1} / \mathrm{Cdk} 2$ complexes, relative to wild-type controls (X. Zou and H. Kiyokawa, unpubl.). These observations also suggest that there is a previously undefined regulatory pathway from Cdk4 to the machinery of $\mathrm{p} 21^{\text {Cip } 1 / \text { Waf1 }}$ degradation. The mechanism of $\mathrm{p} 21^{\text {Cip1/Waf1 }}$ stabilization awaits further investigations.

p16 $6^{\text {Ink4a }}$ is a major Cdk4 inhibitor, and plays a role in senescence-dependent tumor suppression. Forced expression of $\mathrm{p} 16^{\text {Ink4a }}$ inhibits Ras-mediated transformation (Serrano et al. 1995). However, p16 $6^{\text {Ink4a }}$ is dispensable for senescence of primary mouse cells, because p16 ${ }^{\text {Ink4a }}$-null MEFs with intact p19 Arf senesce as well as wild-type MEFs (Krimpenfort et al. 2001; Sharpless et al. 2001). Furthermore, the ability of $\mathrm{Cdk}^{-/-} \operatorname{Ink} 4 \mathrm{a} / \mathrm{Arf}^{-/-}$ MEFs to undergo senescence suggests that $\mathrm{p} 16^{\text {Ink4a }}$ is not required for senescence. However, an antisense RNA construct directed toward $\mathrm{p} 16^{\text {Ink4a }}$ can induce extended lifespan in primary wild-type MEFs (Carnero et al. 2000). The acute loss of $\mathrm{p} 16^{\text {Ink4a }}$ in this experimental system may significantly activate Cdk4 to a level sufficient for prolonged proliferation in the clonogenic assay used for the study. $\mathrm{p} 15^{\text {Ink4b }}$ also participates in Ras-induced senescence, and $\mathrm{p} 15^{\text {Ink } 4 \mathrm{~b}}$-null MEFs exhibit modestly increased sensitivity to Ras-dependent transformation (Malumbres et al. 2000). Our preliminary data demonstrate that siRNA-based suppression of $\mathrm{p} 15^{\text {Ink } 4 \mathrm{~b}}$ minimally affects Ras-mediated foci formation of $\mathrm{Cdk}^{-/-} \mathrm{Ink} 4 \mathrm{a} / \mathrm{Arf}{ }^{-/-}$ MEFs (X. Zou and H. Kiyokawa, unpubl.). Therefore, Cdk4 deficiency facilitates the senescence-mediated tumor-suppressive mechanism specifically in a p21 Cip1/Waf1 dependent manner, whereas the Ink4 inhibitors are dispensable.

The $\mathrm{Rb}$-family pocket binding proteins, that is, $\mathrm{Rb}$, p107, and p130, are involved in the regulation of senescence and immortalization, especially as substrates of Cdk4. Inactivation of these pocket binding proteins by the papillomavirus E7 oncoprotein, together with telomerase activation, has been shown to immortalize primary human epithelial cells (Kiyono et al. 1998). Disruption of $\mathrm{Rb}, \mathrm{p} 107$, and p130 in MEFs results in increased proliferation with shortened G1 phase and immortalization (Dannenberg et al. 2000; Sage et al. 2000). Senescence induced by Ras, Arf, or p53 depends on the repressor activity of E2F (Rowland et al. 2002), suggesting the role of the $\mathrm{Rb} / \mathrm{E} 2 \mathrm{~F}$ pathway also as downstream of Arf/p53 in senescence (Fig. 8A). MEFs with targeted $C d k 4^{\mathrm{R} 24 \mathrm{C}}$ mutation, which express a constitutively active Cdk 4 insensitive to Ink4 inhibitors, exhibit escape from senescence (Rane et al. 2002). Mice with the $C d k 4^{\text {R24C }}$ mutation spontaneously develop various tumors such as endocrine and skin tumors (Sotillo et al. 2001; Rane et al. 2002), supporting the notion that the Cdk4 activity plays a key role in immortalization and transformation. In Cdk4null MEFs, phosphorylation of $\mathrm{Rb}$, especially Ser780, is markedly diminished (Tsutsui et al. 1999). The expression of Cdk6 is unchanged in Cdk4-null MEFs, and thus the role of Cdk6 in cell-cycle progression and immortalization of MEFs remains unclear. The complete restoration of Ras-mediated transformation by E7 suggests that the activities of the $\mathrm{Rb}$-family pocket binding proteins are important for the $A r f / p 53$-independent senescence with Cdk4 disruption.

Efforts are ongoing to identify specific chemical inhibitors of cyclin D/Cdk4 and to apply them to clinical trials (Fry et al. 2001; Honma et al. 2001; Soni et al. 2001). Genetic inactivation of the Ink4a/Arf or p53 locus correlates with poor prognosis in cancer patients, often associated with chemoresistance (Weller 1998; Johnstone et al. 2002). A recent study showed that the senescence response of cancer cells, dependent on these two genetic loci, contributes significantly to the outcome of chemotherapy in vivo (Schmitt et al. 2002). Continuous investigations should clarify how cyclin D/Cdk4 interacts with Ras and Arf/p53 in the process that determines whether cells undergo senescence or immortaliza- 
tion, which should contribute to establishing a solid foundation for therapeutic intervention of the transformation pathways.

\section{Materials and methods}

\section{Cells}

A targeted null mutation of the $C d k 4$ gene, $C d k 4^{\text {tm1Kiyo }}{ }^{\text {, was }}$ created in mouse embryonic stem cells, and mice with germline transmission of this mutation were bred in the recombinant C57BL/6 $\times 129 /$ svj strain background, as described (Tsutsui et al. 1999). MEFs were prepared from day-12.5 mouse embryos and cultured in the Dulbecco's modified minimum essential medium supplemented with $2 \mathrm{mM}$ glutamine, $100 \mathrm{U} / \mathrm{mL}$ penicillin and streptomycin, and 10\% fetal bovine serum (FBS; Life Technology), as described (Tsutsui et al. 1999). MEFs dispersed from each embryo using $0.25 \%$ trypsin solution containing 0.53 mM EDTA were cultured in a $100-\mathrm{mm}$ culture dish (passage 1). Cells were then maintained using a $3 \mathrm{~T} 3$ protocol $\left(3 \times 10^{5}\right.$ cells per $60-\mathrm{mm}$ culture dish passaged every $3 \mathrm{~d}$ ). The population doubling level during each passage was calculated according to the formula $\log \left(\right.$ final cell number $\left./ 3 \times 10^{5}\right) / \log 2$.

\section{Retroviral transfection}

The Phoenix ecotropic virus packaging cells were obtained from the American Tissue Culture Collection (ATCC) with permission of Gary P. Nolan (Stanford University). The pBabe-hygro vector for expression of H-Ras ${ }^{\text {Vall2 }}$ was described previously (Serrano et al. 1996). The LXSN vector for coexpression of DNp53 (GSE56; Ossovskaya et al. 1996) and H-Ras ${ }^{\text {Val12 }}$ was constructed using the internal ribosomal entry site. Phoenix cells were transfected with vectors, using the SuperFect transfection reagent (QIAGEN), and culture supernatants containing infectious retrovirus were harvested $48 \mathrm{~h}$ posttransfection, as described (Pear et al. 1993). The HPV-E7 retrovirus packaging cell line, PA317 LXSN 16E7, was obtained from ATCC. Viruscontaining supernatants were pooled and filtered through a $0.45-\mathrm{mm}$ membrane. Infections of exponentially growing MEFs were performed with $1.5 \mathrm{~mL}$ of various dilutions of virus-containing supernatant supplemented with $10 \mu \mathrm{g} / \mathrm{mL}$ polybrene (Sigma) for each $60-\mathrm{mm}$ culture dish. The dilutions of the $\mathrm{H}$ Ras $^{\text {Val12 }}$ and DNp53+H-Ras ${ }^{\text {Val12 }}$ used were determined according to the numbers of transformed foci developed in $\mathrm{Cdk} 4^{+/+}$ Ink4a/Arf ${ }^{-/-}$and wild-type MEFs, respectively, in pilot experiments. The E7 retrovirus was used at maximum titers without dilution. After $3 \mathrm{~h}$, cells were rinsed and $5 \mathrm{~mL}$ fresh medium was added.

\section{Small interfering RNA (siRNA)}

For suppression of cellular $\mathrm{p} 21^{\mathrm{Cip} 1 / \text { Waf1 }}$ expression, siRNA that specifically targets $\mathrm{p} 21^{\text {Cip1/Waf1 }}$ mRNA was designed according to the manufacturer's protocol (Dharmacon Research). The sense sequence was 5'-AACGGUGGAACUUUGACUUCG-3', corresponding to residues 136-156 of the coding region of mouse $\mathrm{p} 21^{\mathrm{Cip} 1 / \text { Wafl }}$ mRNA. MEFs were transfected with the anti-p21 ${ }^{\text {Cip1/Waf1 }}$ siRNA or random 21-mer dsRNA (Dharmacon), using the Oligofectamine reagent (Life Technologies/Invitrogen) according to the instructions of Dharmacon Research.

\section{Immunoblotting and RT-PCR}

For immunoblotting, cells were lysed by sonication in a Tween20-based lysis buffer, and $50 \mu \mathrm{g}$ of proteins were analyzed by
SDS-PAGE and Western transfer, as described (Tsutsui et al. 1999). Antibodies were obtained from Neomarkers for Ras, Cdk6, and p16 ${ }^{\text {Ink4a }}$; from Santa Cruz Biotechnology for p15 ${ }^{\text {Ink4b }}$ and $\mathrm{p} 21^{\mathrm{Cip} 1 / \text { Waf } 1}$; from Novus Biologicals for $\mathrm{p} 19^{\text {Arf }}$; from Sigma for actin. Immunoreactive bands were visualized using peroxidase-conjugated anti-Ig antibodies and the Supersignal chemiluminescence reagent (Pierce). Signals on X-ray films were quantified with a GS-700 Imaging Densitometer (Bio-Rad). For RT-PCR, RNA samples were prepared using TRIZOL reagent (Life Technologies/Invitrogen). RT reactions were performed using Superscript reverse transcriptase (Life Technologies/Invitrogen). The sequences of primers are $5^{\prime}$-TGTCCAATCCTGGT GATGTCC-3' and 5' -TCAGACACCAGAGTGCAAGAC-3' for p21 $1^{\text {Cip } 1 / \text { Waf } 1 ;} 5^{\prime}$-CCATCACTGCCACCCAGAAG-3' and 5'TGGGTGCAGCGAACTTTATTG-3' for GAPDH. PCR reactions were performed at $92^{\circ} \mathrm{C}$ for $30 \mathrm{sec}, 60^{\circ} \mathrm{C}$ for $30 \mathrm{sec}$, and $72^{\circ} \mathrm{C}$ for $60 \mathrm{sec}$ with 30 cycles, using a DNA Engine thermal cycler (MJ Research). Semiquantitative conditions for the transcripts were worked out using increasing amounts of RNA.

\section{Focus and colony assays}

For transformed focus formation, MEFs were cultured in complete medium with 5\% FBS without splitting, for 14-21 d after retrovirus infection. Medium was changed every $3 \mathrm{~d}$. Confluent monolayer cultures with foci were rinsed with phosphate buffered saline (PBS), and stained with $4 \mathrm{mg} / \mathrm{mL}$ crystal violet in $10 \%$ methanol. Unstained foci of morphologically transformed cells were picked under a phase microscope (Nikon), subcloned by limited trypsinization, and expanded for the tumorigenicity assay. For colony formation in soft agar, MEFs at $48 \mathrm{~h}$ postviral infection were trypsinized, counted, and inoculated at $10^{6}$ cells per $60-\mathrm{mm}$ dish in $0.3 \%$ Noble agar in DMEM supplemented with $10 \%$ FBS. Colonies were scored 21-28 d later. When cells isolated from foci were tested for anchorage-independent growth, $2 \times 10^{4}$ cells were inoculated per dish in the Noble agar medium.

\section{Senescence-associated $\beta$-galactosidase (SA $\beta$-gal) assay}

SA -gal activity at $\mathrm{pH} 6.0$ was assayed as described (Dimri et al. 1995; Chang et al. 1999). Cells were washed with PBS supplemented with $1 \mathrm{mM} \mathrm{MgCl}_{2}$, and then stained in X-gal solution [1 $\mathrm{mg} / \mathrm{mL}$ X-gal, $0.12 \mathrm{mM} \mathrm{K}_{3} \mathrm{Fe}(\mathrm{CN})_{6}, 0.12 \mathrm{mM} \mathrm{K}_{4} \mathrm{Fe}(\mathrm{CN})_{6}, 1 \mathrm{mM}$ $\mathrm{MgCl}_{2}$ in PBS at $\mathrm{pH}$ 6.0] overnight at $37^{\circ} \mathrm{C}$.

\section{Tumorigenicity assay}

For in vivo tumor formation, $10^{6}$ cells isolated and expanded from foci were injected into flanks of 7-wk-old athymic mice (National Cancer Institute). Two mice were used for each clone. Tumor formation was scored every week, and diameters of palpable tumors were recorded.

\section{Acknowledgments}

We thank Barbara Wold for providing Ink $4 a / A f^{-/-}$mice generated in her facility, and Nissim Hay, Pradip Raychaudhuri, Charles Sherr, Igor Roninson, Yinyuan Mo, Xiaoding Peng, Mari Swift, James Artwohl, Rob Streit, and other members of the Kiyokawa laboratory for helpful discussions and advice. This study is supported in part by the American Cancer Society (grant \#RPG-00-043-01-CCG).

The publication costs of this article were defrayed in part by payment of page charges. This article must therefore be hereby 
marked "advertisement" in accordance with 18 USC section 1734 solely to indicate this fact.

\section{References}

Blain, S.W., Montalvo, E., and Massague, J. 1997. Differential interaction of the cyclin-dependent kinase $(\mathrm{Cdk})$ inhibitor p27Kip1 with cyclin A-Cdk2 and cyclin D2-Cdk4. J. Biol. Chem. 272: 25863-25872.

Boyer, S.N., Wazer, D.E., and Band, V. 1996. E7 protein of human papilloma virus-16 induces degradation of retinoblastoma protein through the ubiquitin-proteasome pathway. Cancer Res. 56: 4620-4624.

Boylan, J.F., Sharp, D.M., Leffet, L., Bowers, A., and Pan, W. 1999. Analysis of site-specific phosphorylation of the retinoblastoma protein during cell cycle progression. Exp. Cell Res. 248: 110-114.

Carnero, A., Hudson, J.D., Price, C.M., and Beach, D.H. 2000. p16INK4A and p19ARF act in overlapping pathways in cellular immortalization. Nat. Cell Biol. 2: 148-155.

Chang, B.D., Xuan, Y., Broude, E.V., Zhu, H., Schott, B., Fang, J., and Roninson, I.B. 1999. Role of p53 and p21waf1/cip1 in senescence-like terminal proliferation arrest induced in human tumor cells by chemotherapeutic drugs. Oncogene 18: $4808-4818$.

Coats, S., Whyte, P., Fero, M.L., Lacy, S., Chung, G., Randel, E., Firpo, E., and Roberts, J.M. 1999. A new pathway for mitogen-dependent cdk2 regulation uncovered in p27(Kip1)-deficient cells. Curr. Biol. 9: 163-173.

Connell-Crowley, L., Harper, J.W., and Goodrich, D.W. 1997. Cyclin D1/Cdk4 regulates retinoblastoma protein-mediated cell cycle arrest by site-specific phosphorylation. Mol. Biol. Cell 8: 287-301.

Dannenberg, J.H., van Rossum, A., Schuijff, L., and te Riele, H. 2000. Ablation of the retinoblastoma gene family deregulates $\mathrm{G}(1)$ control causing immortalization and increased cell turnover under growth-restricting conditions. Genes \& Dev. 14: 3051-3064.

de Stanchina, E., McCurrach, M.E., Zindy, F., Shieh, S.Y., Ferbeyre, G., Samuelson, A.V., Prives, C., Roussel, M.F., Sherr, C.J., and Lowe, S.W. 1998. E1A signaling to p53 involves the p19(ARF) tumor suppressor. Genes \& Dev. 12: 2434-2442.

Dimri, G.P., Lee, X., Basile, G., Acosta, M., Scott, G., Roskelley, C., Medrano, E.E., Linskens, M., Rubelj, I., Pereira-Smith, O., et al. 1995. A biomarker that identifies senescent human cells in culture and in aging skin in vivo. Proc. Natl. Acad. Sci. 92: 9363-9367.

Dyson, N., Howley, P.M., Munger, K., and Harlow, E. 1989. The human papilloma virus-16 E7 oncoprotein is able to bind to the retinoblastoma gene product. Science 243: 934-937.

Ewen, M.E., Sluss, H.K., Sherr, C.J., Matsushime, H., Kato, J., and Livingston, D.M. 1993. Functional interactions of the retinoblastoma protein with mammalian D-type cyclins. Cell 73: 487-497.

Ferbeyre, G., de Stanchina, E., Lin, A.W., Querido, E., McCurrach, M.E., Hannon, G.J., and Lowe, S.W. 2002. Oncogenic ras and p53 cooperate to induce cellular senescence. Mol. Cell Biol. 22: 3497-3508.

Fry, D.W., Bedford, D.C., Harvey, P.H., Fritsch, A., Keller, P.R., Wu, Z., Dobrusin, E., Leopold, W.R., Fattaey, A., and Garrett, M.D. 2001. Cell cycle and biochemical effects of PD 0183812. A potent inhibitor of the cyclin D-dependent kinases CDK4 and CDK6. J. Biol. Chem. 276: 16617-16623.

Funk, J.O., Waga, S., Harry, J.B., Espling, E., Stillman, B., and Galloway, D.A. 1997. Inhibition of CDK activity and PCNA- dependent DNA replication by $\mathrm{p} 21$ is blocked by interaction with the HPV-16 E7 oncoprotein. Genes \& Dev. 11: 20902100.

Hanahan, D. and Weinberg, R.A. 2000. The hallmarks of cancer. Cell 100: 57-70.

Hartwell, L.H. and Kastan, M.B. 1994. Cell cycle control and cancer. Science 266: 1821-1828.

Hirama, T. and Koeffler, H.P. 1995. Role of the cyclin-dependent kinase inhibitors in the development of cancer. Blood 86: 841-854.

Honma, T., Yoshizumi, T., Hashimoto, N., Hayashi, K., Kawanishi, N., Fukasawa, K., Takaki, T., Ikeura, C., Ikuta, M., Suzuki-Takahashi, I., et al. 2001. A novel approach for the development of selective Cdk4 inhibitors: Library design based on locations of Cdk4 specific amino acid residues. $I$. Med. Chem. 44: 4628-4640.

Hunter, T. 1997. Oncoprotein networks. Cell 88: 333-346.

Johnstone, R.W., Ruefli, A.A., and Lowe, S.W. 2002. Apoptosis: A link between cancer genetics and chemotherapy. Cell 108: $153-164$.

Kamb, A., Gruis, N.A., Weaver-Feldhaus, J., Liu, Q., Harshman, K., Tavtigian, S.V., Stockert, E., Day III, R.S., Johnson, B.E., and Skolnick, M.H. 1994. A cell cycle regulator potentially involved in genesis of many tumor types. Science 264: 436440.

Kamijo, T., Zindy, F., Roussel, M.F., Quelle, D.E., Downing, J.R., Ashmun, R.A., Grosveld, G., and Sherr, C.J. 1997. Tumor suppression at the mouse INK4a locus mediated by the alternative reading frame product p19ARF. Cell 91: 649-659.

Kato, J., Matsushime, H., Hiebert, S.W., Ewen, M.E., and Sherr, C.J. 1993. Direct binding of cyclin D to the retinoblastoma gene product $(\mathrm{pRb})$ and $\mathrm{pRb}$ phosphorylation by the cyclin D-dependent kinase CDK4. Genes \& Dev. 7: 331-342.

Khatib, Z.A., Matsushime, H., Valentine, M., Shapiro, D.N., Sherr, C.J., and Look, A.T. 1993. Coamplification of the CDK4 gene with MDM2 and GLI in human sarcomas. Cancer Res. 53: 5535-5541.

Kitagawa, M., Higashi, H., Jung, H.K., Suzuki-Takahashi, I., Ikeda, M., Tamai, K., Kato, J., Segawa, K., Yoshida, E., Nishimura, S., et al. 1996. The consensus motif for phosphorylation by cyclin D1-Cdk4 is different from that for phosphorylation by cyclin A/E-Cdk2. EMBO J. 15: 7060-7069.

Kiyokawa, H. 2002. Cell cycle control and cell fate determination: In vivo roles of G1 cyclin-dependent kinases and inhibitors. In Recent research developments in molecular \& cellular biology, Vol. 2 (ed. S.G. Pandalai). Research Signpost, Trivandrum, India (In press).

Kiyokawa, H. and Koff, A. 1998. Roles of cyclin-dependent kinase inhibitors: Lessons from knockout mice. Curr. Top. Microbiol. Immunol. 227: 105-120.

Kiyono, T., Foster, S.A., Koop, J.I., McDougall, J.K., Galloway, D.A., and Klingelhutz, A.J. 1998. Both Rb/p16INK4a inactivation and telomerase activity are required to immortalize human epithelial cells. Nature 396: 84-88.

Krimpenfort, P., Quon, K.C., Mooi, W.J., Loonstra, A., and Berns, A. 2001. Loss of p16Ink4a confers susceptibility to metastatic melanoma in mice. Nature 413: 83-86.

LaBaer, J., Garrett, M.D., Stevenson, L.F., Slingerland, J.M., Sandhu, C., Chou, H.S., Fattaey, A., and Harlow, E. 1997. New functional activities for the p21 family of CDK inhibitors. Genes \& Dev. 11: 847-862.

Leng, X., Noble, M., Adams, P.D., Qin, J., and Harper, J.W. 2002. Reversal of growth suppression by p107 via direct phosphorylation by cyclin D1/cyclin-dependent kinase 4. Mol. Cell Biol. 22: 2242-2254.

Malumbres, M., Perez, D.C., I, Hernandez, M.I., Jimenez, M., 
Corral, T., and Pellicer, A. 2000. Cellular response to oncogenic ras involves induction of the Cdk4 and Cdk6 inhibitor p15(INK4b). Mol. Cell Biol. 20: 2915-2925.

Matsushime, H., Ewen, M.E., Strom, D.K., Kato, J.Y., Hanks, S.K., Roussel, M.F., and Sherr, C.J. 1992. Identification and properties of an atypical catalytic subunit (p34PSK- J3/cdk4) for mammalian D type G1 cyclins. Cell 71: 323-334.

Meyerson, M. and Harlow, E. 1994. Identification of G1 kinase activity for cdk6, a novel cyclin D partner. Mol. Cell Biol. 14: 2077-2086.

Moons, D.S., Jirawatnotai, S., Parlow, A.F., Gibori, G., Kineman, R.D., and Kiyokawa, H. 2002a. Pituitary hypoplasia and lactotroph dysfunction in mice deficient for cyclin-dependent kinase-4. Endocrinology 143: 3001-3008.

Moons, D.S., Jirawatnotai, S., Tsutsui, T., Franks, R., Parlow, A.F., Hales, D.B., Gibori, G., Fazleabas, A.T., and Kiyokawa, H. 2002b. Intact follicular maturation and defective luteal function in mice deficient for cyclin-dependent kinase-4 (Cdk4). Endocrinology 143: 647-654.

Nevins, J.R. 2001. The Rb/E2F pathway and cancer. Hum. Mol. Genet. 10: 699-703.

Ossovskaya, V.S., Mazo, I.A., Chernov, M.V., Chernova, O.B., Strezoska, Z., Kondratov, R., Stark, G.R., Chumakov, P.M., and Gudkov, A.V. 1996. Use of genetic suppressor elements to dissect distinct biological effects of separate p53 domains. Proc. Natl. Acad. Sci. 93: 10309-10314.

Pantoja, C. and Serrano, M. 1999. Murine fibroblasts lacking p21 undergo senescence and are resistant to transformation by oncogenic Ras. Oncogene 18: 4974-4982.

Pardee, A.B. 1989. G1 events and regulation of cell proliferation. Science 246: 603-608.

Pear, W.S., Nolan, G.P., Scott, M.L., and Baltimore, D. 1993. Production of high-titer helper-free retroviruses by transient transfection. Proc. Nat1. Acad. Sci. 90: 8392-8396.

Pestell, R.G., Albanese, C., Reutens, A.T., Segall, J.E., Lee, R.J., and Arnold, A. 1999. The cyclins and cyclin-dependent kinase inhibitors in hormonal regulation of proliferation and differentiation. Endocr. Rev. 20: 501-534.

Pomerantz, J., Schreiber-Agus, N., Liegeois, N.J., Silverman, A., Alland, L., Chin, L., Potes, J., Chen, K., Orlow, I., Lee, H.W., et al. 1998. The Ink4a tumor suppressor gene product, p19Arf, interacts with MDM2 and neutralizes MDM27's inhibition of p53. Cell 92: 713-723.

Pruitt, K. and Der, C.J. 2001. Ras and Rho regulation of the cell cycle and oncogenesis. Cancer Lett. 171: 1-10.

Quelle, D.E., Zindy, F., Ashmun, R.A., and Sherr, C.J. 1995. Alternative reading frames of the INK4a tumor suppressor gene encode two unrelated proteins capable of inducing cell cycle arrest. Cell 83: 993-1000.

Rane, S.G., Cosenza, S.C., Mettus, R.V., and Reddy, E.P. 2002. Germ line transmission of the Cdk4(R24C) mutation facilitates tumorigenesis and escape from cellular senescence. Mol. Cell Biol. 22: 644-656.

Robles, A.I., Rodriguez-Puebla, M.L., Glick, A.B., Trempus, C., Hansen, L., Sicinski, P., Tennant, R.W., Weinberg, R.A., Yuspa, S.H., and Conti, C.J. 1998. Reduced skin tumor development in cyclin D1-deficient mice highlights the oncogenic ras pathway in vivo. Genes \& Dev. 12: 24692474.

Rodriguez-Puebla, M.L., Miliani de Marval, P.L., LaCava, M., Moons, D.S., Kiyokawa, H., and Conti, J.C. 2002. CDK4 deficiency inhibits skin tumor development but does not affect normal keratinocyte proliferation. Am. J. Pathol. 161: 405411.

Rowland, B.D., Denissov, S.G., Douma, S., Stunnenberg, H.G., Bernards, R., and Peeper, D.S. 2002. E2F transcriptional re- pressor complexes are critical downstream targets of p19(ARF)/p53-induced proliferative arrest. Cancer Cell 2: 55-65.

Sage, J., Mulligan, G.J., Attardi, L.D., Miller, A., Chen, S., Williams, B., Theodorou, E., and Jacks, T. 2000. Targeted disruption of the three $\mathrm{Rb}$-related genes leads to loss of $\mathrm{G}(1)$ control and immortalization. Genes \& Dev. 14: 3037-3050.

Schmitt, C.A., Fridman, J.S., Yang, M., Lee, S., Baranov, E., Hoffman, R.M., and Lowe, S.W. 2002. A senescence program controlled by p53 and p16(INK4a) contributes to the outcome of cancer therapy. Cell 109: 335-346.

Serrano, M., Gomez-Lahoz, E., DePinho, R.A., Beach, D., and Bar-Sagi, D. 1995. Inhibition of ras-induced proliferation and cellular transformation by p16INK4. Science 267: 249252.

Serrano, M., Lee, H., Chin, L., Cordon-Cardo, C., Beach, D., and DePinho, R.A. 1996. Role of the INK4a locus in tumor suppression and cell mortality. Cell 85: 27-37.

Serrano, M., Lin, A.W., McCurrach, M.E., Beach, D., and Lowe, S.W. 1997. Oncogenic ras provokes premature cell senescence associated with accumulation of p53 and p16INK4a. Cell 88: 593-602.

Sharpless, N.E. and DePinho, R.A. 1999. The INK4A/ARF locus and its two gene products. Curr. Opin. Genet. Dev. 9: 22-30. . 2002. p53: Good cop/bad cop. Cell 110: 9-12.

Sharpless, N.E., Bardeesy, N., Lee, K.H., Carrasco, D., Castrillon, D.H., Aguirre, A.J., Wu, E.A., Horner, J.W., and DePinho, R.A. 2001. Loss of p16Ink4a with retention of p19Arf predisposes mice to tumorigenesis. Nature 413: 86-91.

Sherr, C.J. 1998. Tumor surveillance via the ARF-p53 pathway. Genes \& Dev. 12: 2984-2991.

Sherr, C.J. 2000. The Pezcoller lecture: Cancer cell cycles revisited. Cancer Res. 60: 3689-3695.

Sherr, C.J. and DePinho, R.A. 2000. Cellular senescence: Mitotic clock or culture shock? Cell 102: 407-410.

Sherr, C.J. and Roberts, J.M. 1999. CDK inhibitors: Positive and negative regulators of G1-phase progression. Genes \& Dev. 13: 1501-1512.

Soni, R., O'Reilly, T., Furet, P., Muller, L., Stephan, C., Zumstein-Mecker, S., Fretz, H., Fabbro, D., and Chaudhuri, B. 2001. Selective in vivo and in vitro effects of a small molecule inhibitor of cyclin-dependent kinase 4. J. Natl. Cancer Inst. 93: 436-446.

Soos, T.J., Kiyokawa, H., Yan, J.S., Rubin, M.S., Giordano, A., DeBlasio, A., Bottega, S., Wong, B., Mendelsohn, J., and Koff, A. 1996. Formation of p27-CDK complexes during the human mitotic cell cycle. Cell Growth Differ. 7: 135-146.

Sotillo, R., Dubus, P., Martin, J., de La, C.E., Ortega, S., Malumbres, M., and Barbacid, M. 2001. Wide spectrum of tumors in knock-in mice carrying a Cdk4 protein insensitive to INK4 inhibitors. EMBO J. 20: 6637-6647.

Stott, F.J., Bates, S., James, M.C., McConnell, B.B., Starborg, M., Brookes, S., Palmero, I., Ryan, K., Hara, E., Vousden, K.H., et al. 1998. The alternative product from the human CDKN2A locus, p14(ARF), participates in a regulatory feedback loop with p53 and MDM2. EMBO I. 17: 5001-5014.

Tsutsui, T., Hesabi, B., Moons, D.S., Pandolfi, P.P., Hansel, K.S., Koff, A., and Kiyokawa, H. 1999. Targeted disruption of CDK4 delays cell cycle entry with enhanced p27Kip1 activity. Mol. Cell Biol. 19: 7011-7019.

Weller, M. 1998. Predicting response to cancer chemotherapy: the role of p53. Cell Tissue Res. 292: 435-445.

Wolfel, T., Hauer, M., Schneider, J., Serrano, M., Wolfel, C. Klehmann-Hieb, E., De Plaen, E., Hankeln, T., Meyer, z.B.K., and Beach, D. 1995. A p16INK4a-insensitive CDK4 mutant targeted by cytolytic $\mathrm{T}$ lymphocytes in a human melanoma. 
Zou et al.

Science 269: 1281-1284.

Yu, Q., Geng, Y., and Sicinski, P. 2001. Specific protection against breast cancers by cyclin D1 ablation. Nature 411: 1017-1021.

Zarkowska, T. and Mittnacht, S. 1997. Differential phosphorylation of the retinoblastoma protein by G1/S cyclin-dependent kinases. J. Biol. Chem. 272: 12738-12746.

Zhang, Y., Xiong, Y., and Yarbrough, W.G. 1998. ARF promotes MDM2 degradation and stabilizes p53: ARF-INK4a locus deletion impairs both the $\mathrm{Rb}$ and $\mathrm{p} 53$ tumor suppression pathways. Cell 92: 725-734.

Zindy, F., Eischen, C.M., Randle, D.H., Kamijo, T., Cleveland, J.L., Sherr, C.J., and Roussel, M.F. 1998. Myc signaling via the ARF tumor suppressor regulates p53-dependent apoptosis and immortalization. Genes \& Dev. 12: 2424-2433.

Zuo, L., Weger, J., Yang, Q., Goldstein, A.M., Tucker, M.A., Walker, G.J., Hayward, N., and Dracopoli, N.C. 1996. Germline mutations in the p16INK4a binding domain of CDK4 in familial melanoma. Nat. Genet. 12: 97-99. 


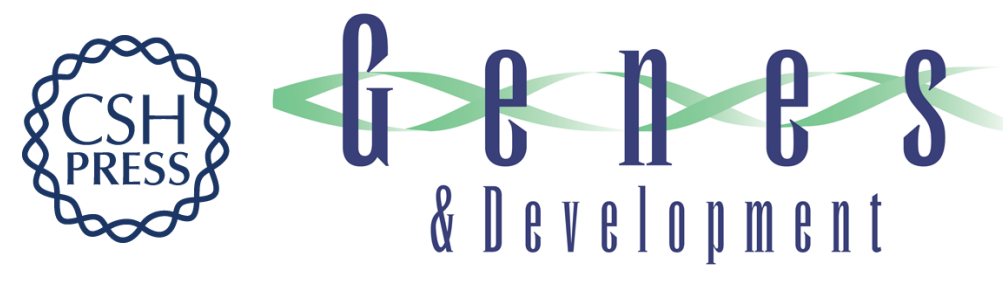

\section{Cdk4 disruption renders primary mouse cells resistant to oncogenic transformation, leading to Arf/p53-independent senescence}

Xianghong Zou, Dipankar Ray, Aileen Aziyu, et al.

Genes Dev. 2002, 16:

Access the most recent version at doi:10.1101/gad.1033002

Supplemental http://genesdev.cshlp.org/content/suppl/2002/12/22/16.22.2923.DC1
Material

References This article cites 73 articles, 36 of which can be accessed free at:

http://genesdev.cshlp.org/content/16/22/2923.full.html\#ref-list-1

License

Email Alerting Receive free email alerts when new articles cite this article - sign up in the box at the top

Service

right corner of the article or click here.

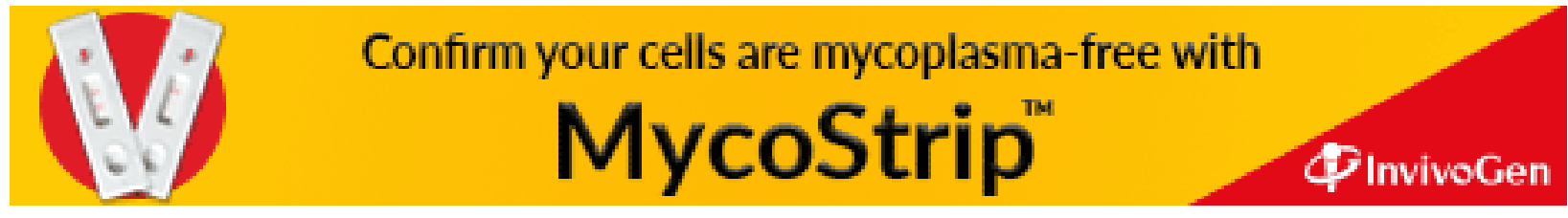

